\title{
Size Matters: The Length of Korea's History and the Size of Its Historical Territory
}

\author{
Remco Breuker
}

The Korean peninsula has a long history. One may quibble about its precise length of course. Little credence should be attached to the conclusions of South Korean pseudo-historians maintaining that the Korean peninsula, its people, and its culture (all proudly singular as if to offer a stark contrast to today's sad duality) ${ }^{1}$ are 5 ,000, 7,00o, or even 9,00o years old..$^{2}$ But serious assertions may be as long as 1,5 oo to 2 ,000 years, the precise number also depending on the precise definitions one uses. Even if one finds oneself forced by reason and fact to position oneself at the shorter end of the bandwidth of potential historical length, as I find myself, the limit of a thousand years is easily crossed. ${ }^{3}$ This, of course, does not mean that human inhabitation of the Korean peninsula only began a mere thousand years ago. Recent archaeological excavations have shown that the Korean peninsula was inhabited by homo sapiens as early as 40,000 years ago. ${ }^{4}$ This must have given occasion for joy among the more jingoistically inclined elements of the Korean population,

1 Or even its triality, if one includes the chosǒnjok or the ethnic Korean Chinese in Yanbian who now see themselves as a nation separate from both North and South Korea.

2 Although I have to confess that the precise mathematics behind this phenomenon escape me, it seems clear that in the discourses of the pseudo-historians, the imagined length of Korean history increases exponentially rather than, as it should, linearly with the passing of the years. While it was still considered properly nationalist in the early 199os to state that Korean history was 5 ,000 years long, ten years later this had increased to 7 , ooo years, while at present it is set at about 9,ooo years. For an informative discussion of pseudo-historians, what they write, and how they behave, see Andrew Miles Logie, Popular Korean Historiography in Northeast Asia: A Critical Survey from the 13th Century until the Present, Pertaining to Early Korea (Helsinki: Univ. of Helsinki, 2016); idem, "The Politics of Feigned Impartiality: A Critical Response to “The Politics of Historical Knowledge," Journal of Asian History 53.1 (2019): 117-50.

3 The conquest of much of what is now seen as the historical territory of the Korean peninsula by Wang Kon in 935 was accompanied by unprecedented (and mostly lasting) territorial, economic, cultural, linguistic and social consolidation across the conquered territory. As such, it makes sense to understand this moment as pivotal in the later emergence of a Korean nation.

4 The perhaps unexpected benefit of a strictly enforced law that obliges a land developer to do an archaeological scan of the land soon to be covered by buildings and, if necessary, carry out long and undoubtedly costly professional archaeological excavations. 
who have a history of consistently and unproblematically bestowing on any group living on the Korean peninsula in prehistoric times the distinction of being Korean, more or less in the contemporary sense of the word (ironically, this distinction is not conferred on more recently arrived groups now living on the Korean peninsula). If, or perhaps when, the alleged total length of Korean history until today is updated to plus-40,0oo years, this should not come as a surprise.

Nonetheless, it is hard to deny that the precise length of the history of the Korean peninsula is indeed an important issue, and not merely because of the purely historical significance (if such a thing an sich exists) of this particular factum. By now, there has been sufficient research to ascertain an all too common observation that in ultranationalist historiography (I use this term with more than a modicum of caution here, given the often stunning lack of even the most basic of historical methods the authors of ultranationalist historiography seem to possess) the length of the nation's history and the size of the nation's territory matter like little else. ${ }^{5}$ Length matters; size matters.

This observation could perhaps have been made as long as four-and-a-half millennia ago, when the mythical emperor Yao 帝堯 ruled China, while on the Korean peninsula Tan'gun 檀君, the progenitor of the Korean people and offspring of a bear-turned-human female and the son of godly being Hwanung, ruled, starting his reign on the third of October in 2333 BCE, a mere four decades into the reign of Yao in China. Emperor Yao and Tan'gun were turning out to be contemparies. The stage had been set for what has essentially turned out to be a still on-going Pisswettbewerb ${ }^{6}$ that entered its fifth millennium over three centuries ago. If, of course, one subscribes to the view that Tan'gun existed (probably not in the form of the son of a former bearess and the son of

5 Although I would be hard put to come up with a rational explanation other than that this is an observable trait, I do wonder whether it is not at some level comparable to the humanities scholar's barely suppressible need to exhaustively and lengthily footnote everything he or she writes, long past the point of useful verification or complementation.

6 I hesitated to use this word in an academic paper, but it cannot be denied that this is an "argument that for most observers struggles to establish any importance beyond the overwhelming sense of its self-importance," as was suggested to me by @KleinpasteThijs on Twitter $(<$ https:// twitter.com/KleinpasteThijs/status/1224003672264318977>, accessed on O2-02-2020). Further suggestions included "pee-r review," "pointless pedantic pedagogery," and "TED talk" (see <https://twitter.com/bluyckx/status/1224033212047011843>, <https://twitter.com/DennisG_ Shea/status/1224024040064671746>, <https://twitter.com/SiccodeKnecht/status/12240o $2063174193156>$, last accessed on $02-02-2020$ ). The relevance and pertinence of these suggestions is hard to deny, but I decided to stay with the original term in German; its connotations are identical to the original term, while its claim to suitability for an academic paper is perhaps even stronger. 
the Heavenly Ruler, but perhaps as a continuous line of proto-Korean shamanrulers, who had taken "Tan'gun" as their title), ${ }^{7}$ even though the first mention of him is in a text dating from almost four millennia after his supposed progenation of the Korean people. If one doubts the early emergence of the Tan'gun myth - it should not pass unnoticed that I am now referring to the emergence of the Tan'gun myth and decidedly not to any kind of historical interpretation of a person or an unbroken line of rulers called Tan'gun - and dates its origin to its first verifiable emergence in the sources (otherwise a well-attested manner of constructing a historical argument), this Pisswettbewerb is younger, though still of a venerable age-about eight hundred years - and lands us smack in the middle of the Koryo 高麗 period (935-1392).

The Koryŏ period is in many ways a relatively forgotten and understudied period in Korean history. It was followed by the Chosŏn 朝鮮 period (13921905), which with its mixture of endless - surviving - archives, traumatic events (such as the Japanese invasions of the late sixteenth century), and a five-century-long presence right before the twentieth century has drawn historians to it as moths to a candle flame. The Koryŏ period is bookended on the other side by a period usually referred to as the Antiquity of the Korean peninsula. Despite the lack of archives and other sources, this period also basks in the attention of scholars, amateur historians, and television producers-although one also has to wonder if it is not precisely the absence of sources that makes this period so attractive. The Koryŏ period's relative absence of source materials (for example, when set next to comparable periods in Japan, China, and other regions) has not led to much scholarly or other interest in the period. The reason for this is prima facie paradoxical, but in fact is not. The contemporary Korean obsession with the size of the nation's territory and the length of its history dates from the Koryŏ period, while later nationalist thinkers designated decisive relevance to certain historical moments in the Koryŏ period, as a consequence of which the period before Koryŏ inevitably came to function as the antecedent for the projection of all kinds of wild historical dreams,

7 There is an embarrassment of riches with regard to theories on Tan'gun Chosŏn 檀君朝鮮, whether it existed at all (although usually this premise is a sine qua non for the construction of serious theories), how it was structured, who ruled it, and of course where it was situated. For completeness sake, it should be mentioned here that just as the 1,500-year long reign of Tan'gun is now understood as mythical and symbolizing the concatenated historical succession of forty-seven different rulers each bearing the title of Tan'gun, Hwan'in 桓因 and Hwan'ung 桓雄 are now seen as pars pro toto for the combined reigns of seven Hwan'in and eighteen Hwan'ung. Of course, one peruses the spurious texts from which the above information has been culled at one's own risk. There is a good reason why these texts were never published in Brill's Korean Studies Library. Its stern but fair gatekeeper A. Hoffstädt made sure of that. 
ambitions, and misinterpretations. Most attention, then, has been lavished on Korean Antiquity, rather than on Koryŏ.

Before I discuss what happened in the Koryo period, let me first refer to some relevant literature on the topic. In a volume on the structural behavior of new religions in Buddhist environments, Blezer et al. argued that "traditional religious histories and antecedents typically are created some time after the facts. Simply put: religious groups start writing respectable histories and laying out their antecedents only somewhat later, when the necessity arises to formulate a self-conscious separate identity, such as may be the case when they are confronted by the presence of an 'other."' 8 The topic here is religious groups but might as well have been other sorts of group: the mechanism holds for all groups establishing and maintaining their identities, it seems. The studies in the Blezer volume make another important observation, succinctly worded in the introduction as follows: "Nativist notions of a local 'self' are systematically reinvented in communication with a dominant foreign 'other.' Identity implies difference after all. Thus nativist discourse is fundamentally predicated on categories of 'self and other.' Emergence of nativist identity discourse is therefore by definition a dynamic and dialogic or multi-logic process." ${ }^{\text {L }}$ Lastly, the introduction notes that "paradoxically and typically, following the power of established discourse, nativist identity discourse tends to frame itself in key terms from the discourse of the dominant other, from which it wishes to stand apart in the first place. ${ }^{\prime 10}$ Keeping the above in mind, it is no wonder, then, that the thirteenth-century Tan'gun myth followed Sinitic examples closely, to the extent of Tan'gun becoming a contemporary of Yao.

The Koryŏ period seems to have been the nursery for all subsequent origin stories, historical fakes and forgeries, et cetera, but it is never acknowledged as such - and it could not possibly be, because for maximum legitimation (or just for the bragging rights) the origins of the nation must be sought as far away as possible, in terms of time and paradoxically also in terms of place. Koryŏ was for all intents and purposes the perfect place for this, because the period of roughly one hundred years between 935 and the 1o3os had seen the creation of the nation of the Three Han or Samhan (三韓), ${ }^{11}$ the nation that inhabited Koryo state and society and would be the historical community that developed into later forms of the nation on the Korean peninsula, including

8 Henk Blezer and Mark Teeuwen, Challenging Paradigms: Buddhism and Nativism: Framing Identity Discourse in Buddhist Environments (Leiden: Brill, 2014), 16.

9 Ibid.

$10 \quad$ Ibid.

11 Remco E. Breuker, Establishing a Pluralist Society in Medieval Korea, 918-1170: History, Ideology, and Identity in the Koryŏ Dynasty (Leiden: Brill, 2010). See the first chapter. 
contemporary North and South Korea. So it is from this period onward that we see a systemic "tradition of inventions" emerge, whenever the party responsible for an invented tradition or historical forgery saw no other way of convincing the majority, of refuting mainstream opinion, of rallying the people, or of defending the country, and chose to depend on a forged artefact or tradition to strengthen its cause.

Koryŏ's "Three Han" nation was codified in the Ten Injunctions (Hunyo shipcho 訓要十條), the alleged deathbed testament of Koryŏ founder T'aejo Wang Kŏn, but in fact an early eleventh-century forgery. ${ }^{12}$ Simultaneously, the borders of the Koryŏ state were set, both in writing and in physical reality: interestingly, the stability of the Koryo frontier (which was inherited by Chosŏn, and then after liberation by North and South Korea together) is nothing short of amazing. In the thousand years since the borders crystallized (really only the northern border counts, since Korea is a peninsula), they have hardly changed (ironically, this is a facet of Korean history that often is missed in nationalist discourse). ${ }^{13}$

The stability of the historical Koryo territory was an excellent platform for its subsequent imagined expansion. Myoch’ŏng 妙淸 (?-1135), Koryŏ rebel, geomancer, and perhaps also monk, built a short-lived rebel movement on the dream of expanding Koryŏ into Manchuria and becoming the center of the world. ${ }^{14}$ Eight centuries later, his dramatic failure to do so (the rebellion started with Myoch'ong losing his head and then failed to get significantly better after that) was reified by Korea's great anti-colonial and anarchist thinker Shin Ch'aeho 申采浩 (1880-1936) as the defining moment when the Korean nation had lost its chance to occupy the territorial size it really deserved..$^{15}$ Shin's arguments are still extremely influential today, in particular but not exclusively among the pseudo-historians who work tirelessly to augment Korea's historical territory and lengthen its history.

Myoch'óng had emphasized a strong "us-versus-others" dichotomy in his ideology, recognizing the necessity to formulate a self-conscious separate identity in opposition to the Song Chinese and Jurchen Jin "others," which according to

12 Remco E. Breuker, Forging the Truth: Creative Deception and National Identity in Medieval Korea, special issue of East Asian History 38 (Canberra: Institute of Advanced Studies, Australian National Univ., 2008).

13 Breuker, Establishing a Pluralist Society.

14 Remco E. Breuker, "Landscape out of Time: 'de-Chronicling' the Landscape in Medieval Korea," Sungkyun Journal of East Asian Studies 7.2 (2007): 69.

15 Shin Ch'aeho 申采浩, Tanjae Shin Ch'aeho chŏnjip 丹齋申采浩全集, ed. Tanjae Shin Ch'aeho sŏnsaeng kinyŏm saŏphoe 丹齋申采浩全集先生記念事業會 (rev. ed., Seoul: Hyŏngsŏl ch'ulp'ansa 형성출판사 , 1995), 2: 103-24. 
his logic must end in the physical conquest of the territories of at least some of the "others" (whose territories were also, confusingly, thought to be ancient Korean territories, inhabited by peoples related to the Korean nation), and had managed to invent a national geomancing tradition that stretched back further than Koryŏ was old. In the early years of the twentieth century, Shin, again, had recognized this and in effect did something very similar, when he emphasized in his writings that "history is a struggle of us and those who are not us."16 His work then laid the intellectual and ideological (not so much historical) foundation for others to claim even more size and even more length for the Korean nation: to Shin, Myoch'ong's failure was the "most important event in the last thousand years of Korean history" and the moment when everything could have gone in a better-dare one say expansionist and imperialist-direction. Imagined imperialism is, then, I think, one way to characterize Shin's longing for a Great Korea. It should not escape notice that these longings were formulated in the context of a colonial situation, a colonial prison, and exile abroad.

In the meantime, in the realm of imagined communites, Great Korea has since been realized time and again. Building on Myoch'ŏng's failed first attempt and Shin's canonization of Myoch'ǒng's notions as normative for nationalist historians, even in Shin Ch'aeho's own time intellectuals such as Ch'oe Namsŏn 崔南善 (1890-1957) had taken up the challenge of enlarging historical Korea's size and age. ${ }^{17}$ Ch'oe's far-fetched hypotheses, based on the application of historical linguistics as practiced in Japan at that time by famous scholars such as Shiratori Kurakichi 白鳥庫吉 $\left(1865^{-1942}\right)$ but with a Korean inflection, proved popular; but other intellectuals quickly spotted the fatal weak link in Ch'oe's (and Shin's, for that matter) armor: a lack of hard facts to support their grand narratives of the rise and fall of the ancient Korean empire. Commensurate with the rediscovery (although it never had been really lost), reevaluation, annotation, and publication of the first authentic Korean historical text to mention Tan'gun (the thirteenth-century Samgukyusa 三國遺事, The Memorabilia of the Three Kingdoms), other "ancient texts" began to surface, each one filling in more gaps of Korea's grand past before Koryŏ. The rediscovery of ancient texts continues until today, although strikingly, with the loss of active

16 Shin Ch'aeho, Tanjae Shin Ch'aeho chŏnjip, 1: 31.

17 Interestingly, Ch'oe was one of the historians who did so in a format and with a methodology immediately recognizable to the colonizer, confirming the theory that "following the power of established discourse, nativist identity discourse tends to frame itself in key terms from the discourse of the dominant other, from which it wishes to stand apart in the first place." Blezer and Teeuwen, Challenging Paradigms, 16; Remco E. Breuker, "Contested Objectivities: Ikeuchi Hiroshi, Kim Sanggi and the Tradition of Oriental History (Tōyōshigaku) in Japan and Korea," East Asian History 29 (2005): 69-107. 
command of Literary Chinese by Korean intellectuals, which was the distinctive ability of the Korean intellectual, these days conveniently the Korean translations of ancient texts are found - their original versions in a lost Korean script and language and subsequent translation in Literary Chinese long lost. While texts such as the Hwandan kogi 桓檀古記, Kyuwŏn sahwa 揆園史話, and Pudoji 符都誌 have generally been recognized as forgeries, other such texts, such as Tan'gi kosa 檀奇古史 or Hwarang segi 花郎世記, are still receiving academic attention..$^{18}$ A quick Google search for the “Hwan Empire 桓帝國” teaches that this ancient Korean empire-where the Hwan'in, Hwangun, and Tan'gun had ruled for many generations-is thought to have encompassed the lands of Asterix and Obelix, at least by some ultranationalist groups. ${ }^{19}$ This, incidentally, would explain the presence of uncannily similar menhirs and dolmens in both ancient Korea and ancient Gaule ${ }^{20}$ — as ancient Korea's possession of Siberia (for which many colorful theories have found linguistic evidence, mainly on the Korean side) would explain the presence of shamans among Native Americans.

The Hwan Empire-which incidentally bears an interesting cartographical resemblance to the Mongol Empire, but which other than the aforementioned empire seems to have left no archaeological or textual traces - was built on the spurious historical forgeries of the early twentieth century, which in turn built upon the work of serious scholars and nationalists such as Ch'oe Namsonn and Shin Ch'aeho. Their work, which given its contents and obsessive navel gazing may perhaps be somewhat reductively understood as nativist (or neo-nativist) historiography, built upon the in-principle solid foundations of a classical education and traditional source materials, as well as on the fleeting dreams of tragically failed imperialists such as Myoch'ŏng. It was done so in extreme urgency; the Korean state had disappeared and the nation was in danger of

18 Although admittedly situated more towards the margins of the discourses of professional historians, nonetheless the authenticity of these texts-which both in terms of provenance stories and with regard to their contents immediately invite extreme scepticism about their status as bona fide historical documents—is defended by members of the community of professional historians.

19 Try it yourself by clicking here: $<$ https://www.google.com/search?newwindow=1\&ei=TIU 4XoqYKO6arfAPhN2e4Aw\&q=korean+hwan+empire\&oq=korean+hwan+empire\&gs_ l=psy-ab.3..33i16ol2.3116.6o56..6151...o.4..o.118.1789.5j12..............gws-wiz.......oi71jojoi67joi2 2i3ojoi22i1oi3oj33i21.SSmjrUAVPJQ\&ved=oahUKEwiK7vP_nrbnAhVuTRUIHYSuB8wQ4d UDCAs\&uact $=5>$.

20 I wish to express my gratitude to the anonymous reviewer who turned out to be an expert in Astérix and Obélix and pointed out that I had made a serious error in mistakenly identifying ancient Bretagne as the place they lived, while it should have been Gaule or Armorique ( or "Gaule armoricaine"). 
undergoing the same fate. Respectable historical narratives were needed, but the established discourse was now Japanese, Western, foreign by any account, and nativist historians framed their own history using the methodology and terminology of others. As a result, it became impossible for nativist or nationalist Korean historians to distinguish themselves through the methodology and frameworks they used: these had after all been taken from mainstream colonial(-ist) discourse to ensure maximum prestige. The only avenue left to plead Korean distinctiveness, then, was by appealing to facts no other nation could lay claim to or could possibly rival. Hence the insatiable need of nationalists for a longer history, a larger territory, more battles won, and so on and so forth. The irony is killing: for the facts used to bludgeon any opposition to nationalist narratives of Korean history (which would morph into the ultranationalist narratives of contemporary South Korea, but without a mitigating context to make them understandable and reasonable), were by necessity fake facts. The Korean nation (or one of its antecedents) had emerged in Koryŏ. From there, a search for a longer history had started, by definition by looking backwards, even if there was little to no empirical evidence to suggest success.

The inevitable conclusion is that size matters. Length matters. Facts, only insofar as they support the empirically demonstrable ever increasing of the size of a nation's territory and the length of its history. And while reaching back chronologically should only have to give rise to imagined clashes over contested territories in time, the same is not true for size. One's neighbor's borders usually provide a firm obstacle on the path to territorial expansion; hence, perhaps, the fanatical occurrence of imagined territorial expansions, such as that of the Hwan empire - an imagined empire then to be defended against the assaults of the professional historian. It is clear that the world at large is better off with imagined imperialism, rather than its real, off-line cousin. It does keep professional academics quite busy, though, given the efforts and time they must continue to put in debunking pseudo-histories and the like. A corollary conclusion to the above is that good intentions do not matter. The seriousness and integrity with which scholars such as Shin Ch'aeho thought and wrote has proven to be no match for all those after him who have lionized his work and made off with it. A somewhat somber conclusion to end this essay with, perhaps, but also one that amply demonstrates-as do the references cited herein - that in this struggle, the availability of thoroughly reliable studies, texts, libraries, et cetera, meticulously curated by a highly-skilled editor remain of the utmost importance. 